\title{
Study of thermo-hydro-mechanical processes at a potential site of an Indian nuclear waste repository
}

\author{
Sachin Maheshwar ${ }^{1}$, A K Verma ${ }^{1, *}$, T N Singh ${ }^{2}$ and R K Bajpai ${ }^{3}$ \\ ${ }^{1}$ Department of Mining Engineering, Indian School of Mines Dhanbad, Dhanbad 826 004, India. \\ ${ }^{2}$ Department of Earth Sciences, Indian Institute of Technology Bombay, Powai, Mumbai 400 076, India. \\ ${ }^{3}$ Technology Development Division, Nuclear Recycle Group, Bhabha Atomic Research Centre, \\ Mumbai 400 076, India. \\ *Corresponding author. e-mail: neurogeneticamit@gmail.com
}

A detailed scientific study is required for the disposal of high-level radioactive wastes because they generate extremely high heat during their half-life period. Although, several methods have been proposed for the disposal of nuclear wastes, deep underground repository is considered to be a suitable option.

In this paper, field investigation has been done near to Bhima basin of peninsular India. Detailed fracture analysis near the borehole shows very prominent maxima of fractures striking $\mathrm{N} 55^{\circ} \mathrm{E}$ coinciding with the trace of master basement cover metasediment fault. Physico-mechanical properties of rocks have been determined in the laboratory.

The host rock chosen is granite and engineered barrier near the canister is proposed to be clay. A thermo-hydro-mechanical (THM) analysis has been done to study the effect of heat on deformations, stresses and pore-pressure variation in granite and clay barriers. For this purpose, finite difference method has been used. Suitable rheological models have been used to model elastic canister and elasto-plastic engineered barrier and host rock. It has been found that both temperature and stresses at any point in the rockmass is below the design criteria which are $100^{\circ} \mathrm{C}$ for temperature and 0.2 for damage number.

\section{Introduction}

Nuclear energy has been a source of clean power and is not based on non-renewable fossil-based energy sources. Nuclear power produces high-level and low-level radioactive wastes with long half-life time periods. The major problem is due to the generation of long-lived high-level nuclear wastes (HLW) and its safe disposal. Although the level of radioactivity of these wastes decay over time, it remains dangerously high that it must be isolated from the outer atmosphere, until it has decayed to levels that pose less risk.

It is necessary to study the several processes at excavation stage in an underground repository laboratory and supplemented by surface-based and traditional laboratory tests. Underground research laboratories (URLs) (figure 1) are being developed in several countries to address the fundamental questions on whether or not a particular rock type or rock mass would be suitable as a host medium for nuclear repository.

The design of a nuclear waste repository involves modelling a complex system of physical mechanism that operate over a long period of time. Both short and long term thermo-hydro-mechanical (THM) processes should be considered which are caused by both the engineering excavation and the waste heat.

Over the past two decades, nuclear disposal programs around the world have devoted considerable resources to the development of thermo-hydromechanical (T-H-M) modelling (e.g., Booker and

Keywords. THM; FLAC; nuclear waste; underground research laboratory; HLW. 


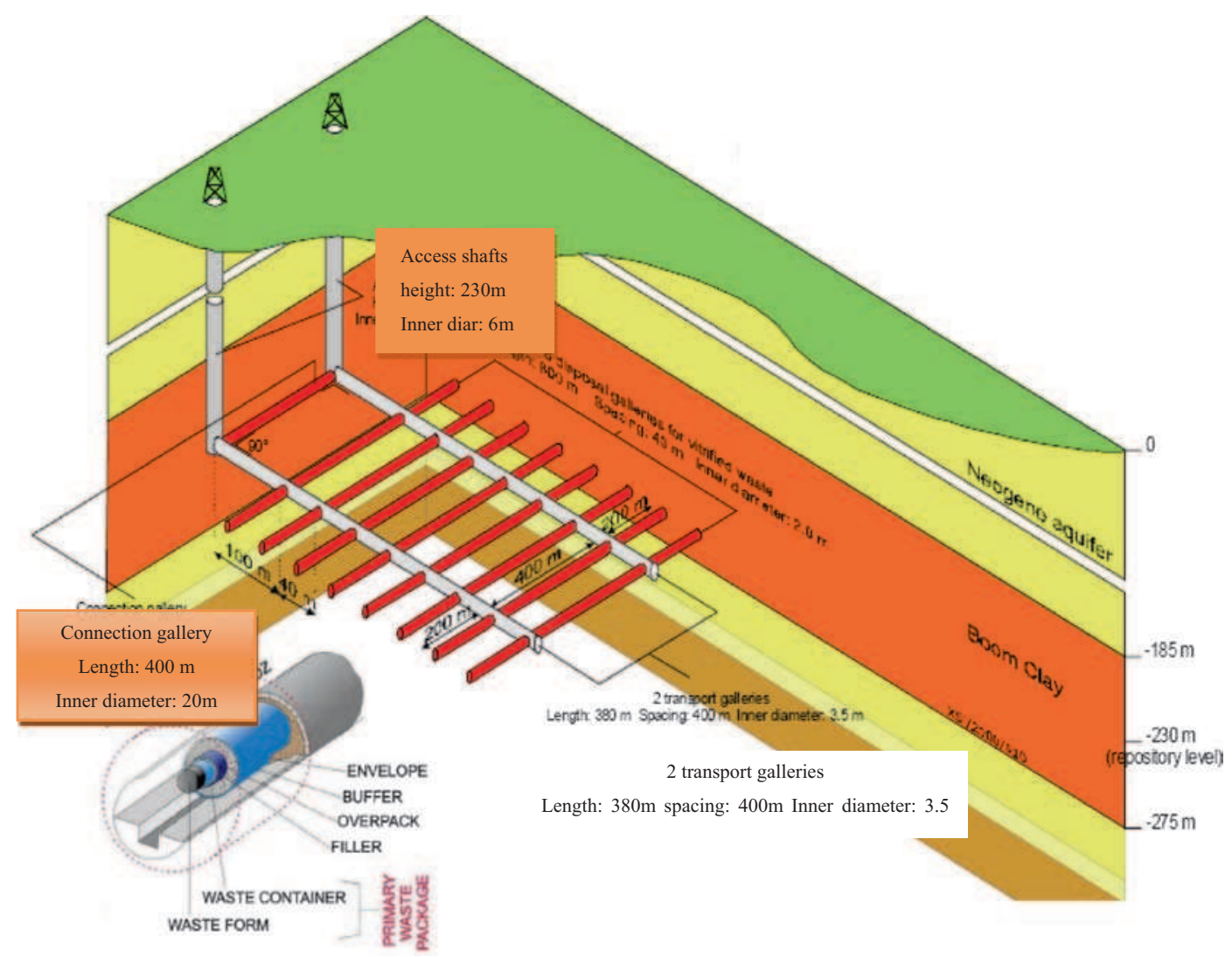

Figure 1. A typical underground research laboratory (Sillen 2008).

Savvidou 1985; Guvanasen 1985; Radhakrishna et al. 1992; Chan et al. 1995; Thomas et al. 1996; Berchenko 1998; Thomas et al. 1998; Ledesma and Chen 2003; Thomas et al. 2003). Most of these focussed on heat flow, thermally-induced pore water pressure and ground water flow, thermally-induced stresses and displacements and solute transport in fractured rock mass. In order to assess the suitability of engineered barrier system technology, to monitor coupled T-H-M processes in situ and to increase confidence in coupled T-H-M or thermohydro-mechanical-chemical (T-H-M-C) models, a number of physical tests have been conducted. These include the Kamaishi Mine Heater Experiments in Japan (Chijimatsu et al. 2001), the FEBEX in situ test in Switzerland (EURATOM 2000), the Yucca Mountain Drift Scale Test in Nevada, USA (Rutqvist et al. 2005) and the Buffer/ Container Experiment in Canada (Kjartanson and Gray 1987; Graham et al. 1997). The DECOVALEX project, an international collaboration, has been carried out to improve the understanding and modelling of coupled T-H-M processes since 1992 (Jing et al. 1995; Stephansson et al. 1999; Alonso et al. 2005; Guo and Dixon 2006).

\section{Indian reference disposal system}

The Indian programme on geological repository commenced in the early eighties with underground experiments in an abandoned section of a gold mine at a depth of $1000 \mathrm{~m}$. The investigations were mainly directed towards development of methodology for in situ assessment of thermo-mechanical behaviour of the host rock (amphibolite) and to develop and validate the mathematical models (Mathur et al. 1998). It also addressed the development of associated instrumentation for the measurements and monitoring.

The investigations involve extensive geo-scientific investigations and other state-of-the-art methods and technologies. Major attributes of significance considered at each site for selection include lithological formation, seismicity, rainfall, economic mineral occurrences, geohydrology, vegetation cover, population, archaeological monuments, etc. The above methodologies have led to screening of an area of nearly 0.6 million $\mathrm{km}^{2}$ mainly occupied by granites. The above approach has yielded a few zones measuring $5-25 \mathrm{~km}^{2}$ lying in different geographic domains for further characterization (Raj et al. 2006). 


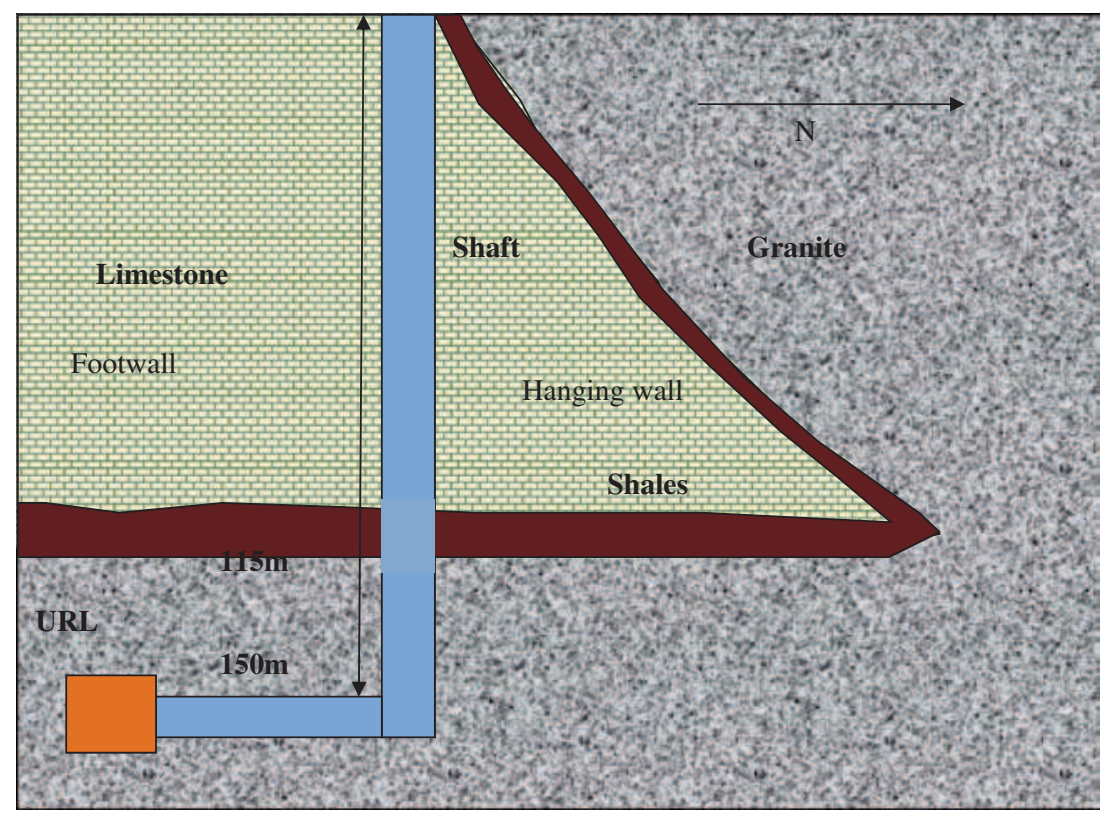

Figure 2. Schematic section showing URL at $150 \mathrm{~m}$ depth.

A layout for a URL has been conceived based on site-specific investigations. The considered URL design has multiple chambers for in situ experiments to generate design data for geological repository in future. The layout considered, extends over an area of about $4 \mathrm{~km}^{2}$ and considers emplacement of around 10,000 high-level waste overpacks on a pit mode. It is proposed to have four main tunnel branching from the central shaft. Each main tunnel will have disposal tunnels on either side with boreholes to emplace the radioactive waste overpacks. A vertical downward shaft of $125 \mathrm{~m}$ has been excavated from the surface (figure 2). A crosscut of $300 \mathrm{~m}$ length has been excavated to reach the URL which is inside the granitic rock. A second small crosscut has also been planned which is at $65 \mathrm{~m}$ from the surface having length of $30 \mathrm{~m}$. A total of six boreholes have been made with total drilling length of $2600 \mathrm{~m}$. Two ventilation shafts of 24 inch diameter have excavated which reaches URL from the surface. Design constrains, namely temperature less than $100^{\circ} \mathrm{C}$ in order to avoid the change of state of water and subsequent design complexities, strength/stress ratio greater than 0.2 for full-scale disposal in disposal tunnel, have been proposed. Hydrogeological and radionuclide transport experiments have been planned inside the URL.

The model consists of an underground repository which is located in granitic rock at about $150 \mathrm{~m}$ below the surface. Canisters with diameter of $0.35 \mathrm{~m}$ are placed in vertical boreholes to a depth of $1.5 \mathrm{~m}$ from the floor of tunnel. Canister is of length 2.05. The migration of the radionuclides from the disposed high level waste will be prevented by engineered barriers like steel canisters and clay barrier.

\section{Regional geology and structure}

Site near to Bhima basin is found to be suitable for URL site. Bhima basin is the smallest and youngest amongst the Proterozoic basins of peninsular India. The basin receives it name after 'Bhima River' a major tributary to the river Krishna. The basin is exposed between lat. $16^{\circ} 20^{\prime} 00^{\prime \prime}-17^{\circ} 35^{\prime} 00^{\prime \prime} \mathrm{N}$ and long. $76^{\circ} 15^{\prime} 00^{\prime \prime}-77^{\circ} 44^{\prime} 00^{\prime \prime} \mathrm{E}$ on the northwestern fringe of eastern Dharwar Craton. The basin has a reverse sigmoidal array of outcrops between Tandur in the northeast and Muddebihal in the southwest, for over a stretch of $160 \mathrm{~km}$ with a maximum width of $40 \mathrm{~km}$ across Sedam. The exposed area of the basin is about $5200 \mathrm{~km}^{2}$. Northern and northwestern extensions are concealed under Deccan traps. The southern and eastern margins of the basin mark the 'unconformity contact' with granitic gneisses and younger granites of Dharwar Craton.

\section{Stratigraphy at URL site}

The structure comprises of a major thrust plane striking NE-SW with granitic rocks riding over limestone. The eagle beak structure offers two possibilities of encountering granite rocks at depth for locating a URL. The regions lying to the east and southeast of the surface trace of the thrust plane constitute the hanging wall of the structure and exposes granites on the surface itself. 
The thrusted contact of limestone and granite narrows down towards north and has the maximum width to the southeast of the shaft. The thrust plane is thus curvilinear dipping towards SE and striking NE-SW. The thrust plane is marked by intense shearing and shattering of rock in the contact zone. The shale layer defining the contact between Proterozoic limestone and granite basement has undergone conspicuous thinning along the margin of hanging wall block. On the other hand, there is no substantial thinning in the shale layer covering basement granites towards western side of the thrust plane indicating less degree of deformation in footwall side of the thrusted block.

\section{Field and laboratory investigations}

The rock samples were collected from the above study area during various site visits to understand their physico-mechanical, thermal and hydraulic behaviours in different states of stress. The samples were obtained from six boreholes at depth ranging from 68 to $150 \mathrm{~m}$.

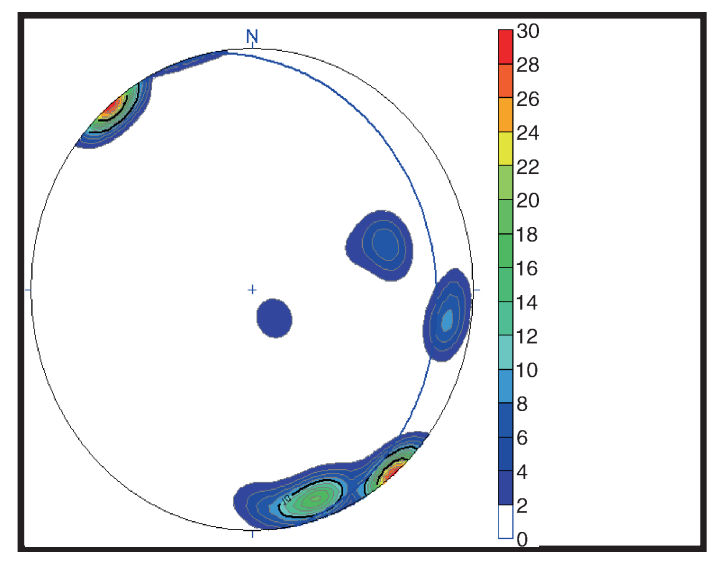

Figure 3. Equal area plot of fractures measured in outcrops.
The area around URL shaft was geologically surveyed for outcrop studies leading to collection of data on fractures and joints. A total of 64 fractures were measured for fracture analysis. The bearings of these fractures were plotted on a rose diagram (figure 3). The plot shows very prominent maxima of fractures striking $\mathrm{N} 55^{\circ} \mathrm{E}$ coinciding with the trace of master basement cover metasediment fault. The other prominent set strikes $\mathrm{N} 330^{\circ} \mathrm{W}$ coinciding with trace of cross faults. Besides, a few random orientations are also noticed. These include $\mathrm{N}-\mathrm{S}$ and $\mathrm{E}-\mathrm{W}$ fractures.

A total of 323 fractures have been recorded in $140 \mathrm{~m}$ long core samples obtained from borehole number six. The average fracture frequency of the borehole is thus $<3$ fracture $/ \mathrm{m}$. The location of

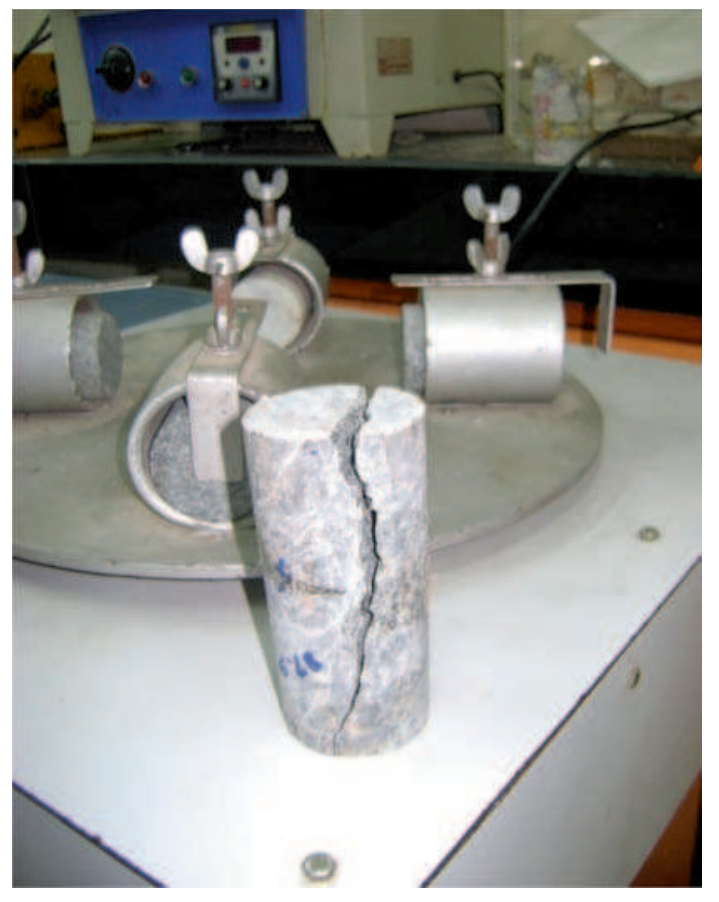

Figure 4. Fracture developed after UCS test.

Table 1. Variation of physico-mechanical parameters with depth.

\begin{tabular}{|c|c|c|c|c|c|c|c|c|c|}
\hline \multirow{2}{*}{$\begin{array}{l}\text { Sample nos. } \\
\text { of granite }\end{array}$} & \multicolumn{2}{|c|}{ Depth } & \multirow{2}{*}{$\begin{array}{c}\mathrm{UCS} \\
\left(\sigma_{\mathrm{c}}\right) \\
(\mathrm{MPa})\end{array}$} & \multirow{2}{*}{$\begin{array}{c}\text { Tensile } \\
\text { strength } \\
\left(\sigma_{\mathrm{t}}\right) \\
(\mathrm{MPa})\end{array}$} & \multirow{2}{*}{$\begin{array}{l}\text { Cohesive } \\
\text { strength, } \\
\mathrm{C}(\mathrm{MPa})\end{array}$} & \multirow{2}{*}{$\begin{array}{c}\text { Angle of } \\
\text { internal } \\
\text { friction, } \\
\Phi \text { (Degree) }\end{array}$} & \multirow{2}{*}{$\begin{array}{l}\text { Young's } \\
\text { modulus } \\
(\mathrm{GPa})\end{array}$} & \multirow{2}{*}{$\begin{array}{l}\text { Poisson's } \\
\text { ratio }\end{array}$} & \multirow{2}{*}{$\begin{array}{c}\text { Density } \\
(\mathrm{g} / \mathrm{cc})\end{array}$} \\
\hline & From & To & & & & & & & \\
\hline 1 & 68.25 & 77.25 & 130.00 & 10.83 & 59.0 & 54.0 & 51.24 & 0.21 & 2.588 \\
\hline 2 & 77.25 & 86.25 & 120.00 & 10.00 & 57.0 & 50.0 & 49.35 & 0.23 & 2.590 \\
\hline 3 & 86.25 & 95.25 & 110.00 & 9.17 & 58.0 & 51.0 & 53.54 & 0.22 & 2.618 \\
\hline 4 & 95.25 & 104.25 & 120.78 & 10.07 & 59.8 & 55.0 & 51.22 & 0.23 & 2.620 \\
\hline 5 & 104.25 & 113.25 & 124.36 & 10.36 & 64.0 & 58.2 & 60.21 & 0.24 & 2.610 \\
\hline 6 & 113.25 & 122.25 & 134.18 & 11.18 & 63.5 & 56.0 & 52.46 & 0.23 & 2.612 \\
\hline 7 & 122.25 & 131.25 & 140.00 & 11.67 & 62.0 & 55.0 & 51.34 & 0.24 & 2.616 \\
\hline 8 & 131.25 & 140.25 & 135.24 & 11.27 & 65.5 & 59.0 & 52.16 & 0.25 & 2.614 \\
\hline 9 & 140.25 & 149.25 & 101.58 & 8.47 & 63.0 & 58.5 & 53.24 & 0.23 & 2.624 \\
\hline 10 & 149.25 & 158.25 & 150.48 & 12.54 & 63.5 & 58.0 & 54.25 & 0.23 & 2.621 \\
\hline
\end{tabular}


this borehole away from the trace of the cross faults has resulted in absence of well-defined crush/ cataclastic zones.

Variation of rock quality designation (RQD) with depth of one of the borehole is given in figure 7 which indicates the depth of suitable URL site between 130 and $150 \mathrm{~m}$. Both destructive and nondestructive tests were conducted as per standards of International Society of Rock Mechanics (ISRM 1981a) to characterize the physico-mechanical properties of the rocks present at different depths (table 1). Uniaxial and triaxial tests on rock specimens prepared from cores obtained from above boreholes at different depths were determined (figure 4) as per ISRM (1981b) suggested technique.

\section{Numerical modelling}

To investigate the effect of heat flux around the single pit mode disposal with one OP, thermohydro-mechanical (THM) coupling analysis have been

Table 2. Dimensions of different EBs.

\begin{tabular}{lc}
\hline $\begin{array}{l}\text { Engineered } \\
\text { barrier }\end{array}$ & $\begin{array}{c}\text { Diameter } \\
\text { of EB (m) }\end{array}$ \\
\hline EB1 & 0.55 \\
EB2 & 0.75 \\
EB3 & 0.95 \\
EB4 & 1.15 \\
EB5 & 1.35 \\
\hline
\end{tabular}

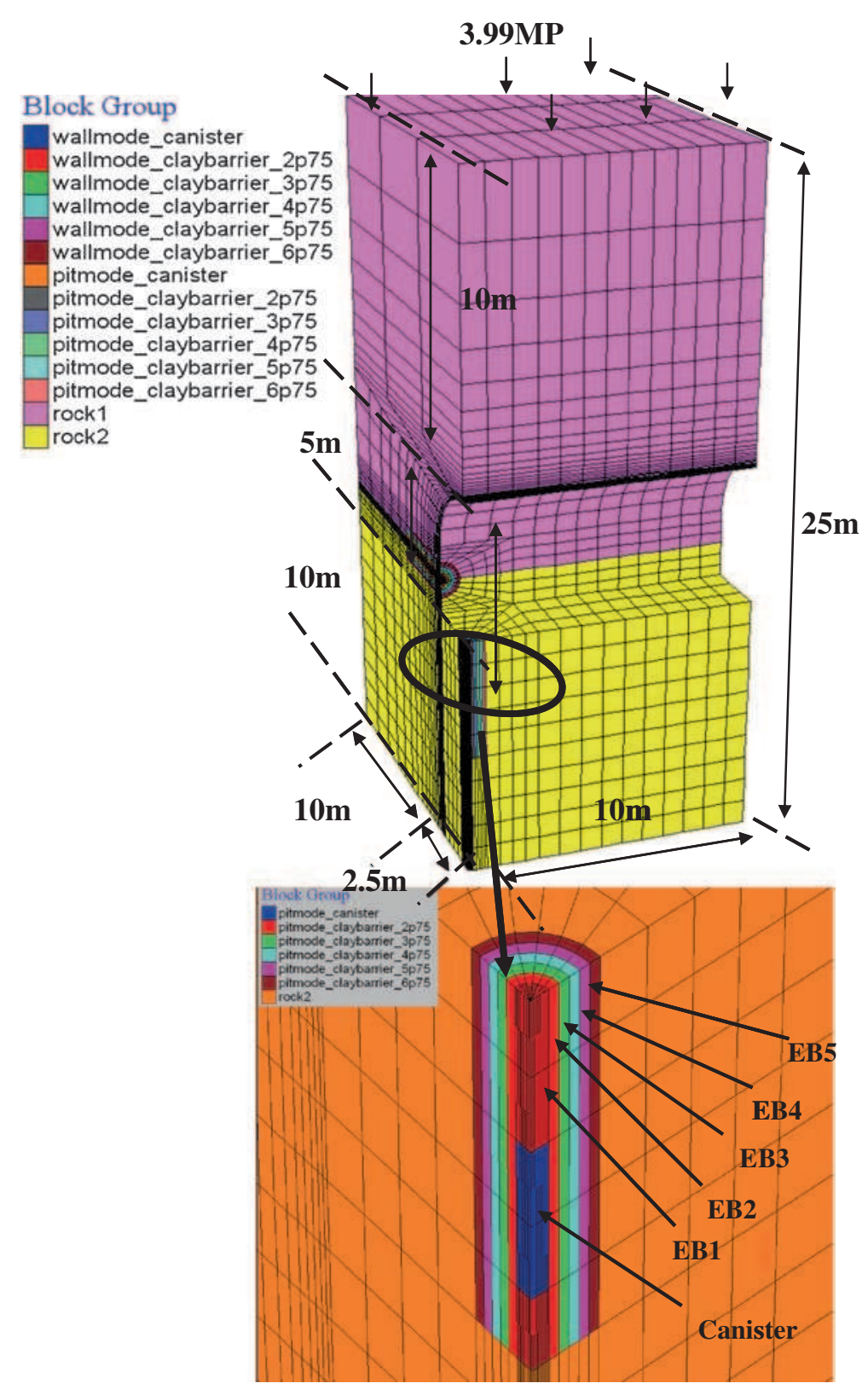

Figure 5. Model mesh for single pit mode disposal with one OP. 
carried out using a three-dimensional FDM code, $\mathrm{FLAC}^{3 \mathrm{D}}$. Mesh of the model has been generated for this case (figure 5). Five layers of engineered barrier (EB), each with a depth of $4.05 \mathrm{~m}$ has been modelled with dimensions shown in table 2 . The diameter of the spent fuel canister was $0.35 \mathrm{~m}$, while the length was $2.05 \mathrm{~m}$. Dimensions of the tunnel, barrier, spent fuel and overburden are shown in figure 5 .

Only $10 \mathrm{~m}$ overburden of granitic rock has been modelled and vertical stress of 3.99 $\mathrm{MPa}$ has been applied on the top surface of the model to take into account of remaining $150 \mathrm{~m}$ overburden (which has not been modelled explicitly) as shown in figure 5 . The properties of the spent fuel were determined with the assumption that the fuel and canister were uniformly mixed. Buffer and surrounding granitic properties were derived from the laboratory tests. The width, length and height of the initial model mesh were 12.5, 12.5 and $160 \mathrm{~m}$, respectively. Total number of zones in the model meshes were 11,750.

\section{Rheological behaviour}

Three types of rheological behaviour were taken into account which simulates the behaviour of steel plus spent fuel canister, EB and surrounding granitic rock. Canister is modelled using elastic constitutive model, EB sand were modelled using elasto-plastic Mohr-Coulomb (MC) material and crystalline (granitic) rock were modelled using Hoek-Brown constitutive model given by Hoek et al. (2002).

\section{In-situ stress}

Hydraulic fracturing tests were conducted in a vertical borehole and the maximum horizontal stress was in a direction of ES-SW. Different initial stress ratios $(K)$ for the model were used to simulate the measured in situ stress condition and finally $\mathrm{K}=$ 1.5 was chosen for the final model mesh.

\section{Heat decay}

Heat from the waste canister decays exponentially (KAERI 2005). The wastes generated from the Indian nuclear power plant follows following equations:

$$
\mathrm{P}(\mathrm{t})=\mathrm{P}\left(\mathrm{t}_{0}\right) \mathrm{e}^{(\text {deconst* } \mathrm{t})},
$$

where deconst is $-7.32496 \mathrm{e}-10$ and $\mathrm{t}$ is the elapsed time (sec) after placing the spent fuel into the pit. $\mathrm{P}\left(\mathrm{t}_{0}\right)$ is initial heat flux as a volume source of heat (Dutt et al. 2012). The value of decay constant is arrived based on authors' discussion with Indian nuclear agency (BARC).

Waste canister has been assumed to have initial power of $1.0 \mathrm{KW}$. Since, only quarter of the canister has been considered so, a volume source of $0.25 \mathrm{KW}$ has been used in this case. Subsequent heating of rock mass by heat-generating waste will increase the stresses in the buffer and the surrounding rock mass because of thermal expansion. This phenomenon is more pronounced near canister and barrier interface of OP. Because of the higher thermal expansion of water than that of rock, the heat from the canister will increase the pore pressure in the rock and especially in the clay barrier. This will lead to higher hydraulic gradients around the deposition hole and influences the hydraulic behaviour of the clay barrier and rock mass near to the canister.

\section{Initial and boundary conditions}

There are three types of boundary conditions which have been applied to the model:

(1) Mechanical,

(2) flow, and

(3) thermal.

Roller boundary conditions have been applied to the left and right boundaries, bottom is fixed and the nodes at the upper boundary are free in $\mathrm{X}, \mathrm{Y}$ and $\mathrm{Z}$ directions. No flow boundary conditions were applied on all the four sides of the model. Similarly, adiabatic boundary conditions were used for all sides of the model. The initial and boundary conditions for the mechanical, thermal and hydraulic effects are shown in figure 6 .

Fluid flow inside the canister has been neglected and hence no fluid model has been assigned to canister. Tunnel was saturated up to a height of $9 \mathrm{~m}$ above tunnel crown. Initial pore pressure of $5 \mathrm{e} 4$ $\mathrm{Pa}$ with gradient of $-0.625 \mathrm{e} 4 \mathrm{~Pa}$ up to tunnel center and a gradient of $-5 \mathrm{e} 4 \mathrm{~Pa}$ to the bottom of the center has been applied to include the water table effect. A vertical stress of 3.99 MPa has been applied to the top surface of the model to simulate the effect of $147.5 \mathrm{~m}$ of granitic overburden (figure 6).

\section{Mechanical, hydraulic and thermal properties}

Tables 3, 4 and 5 list the results of physicomechanical laboratory tests of granite and buffer samples, thermal and hydraulic properties of granite and buffer material, respectively. 


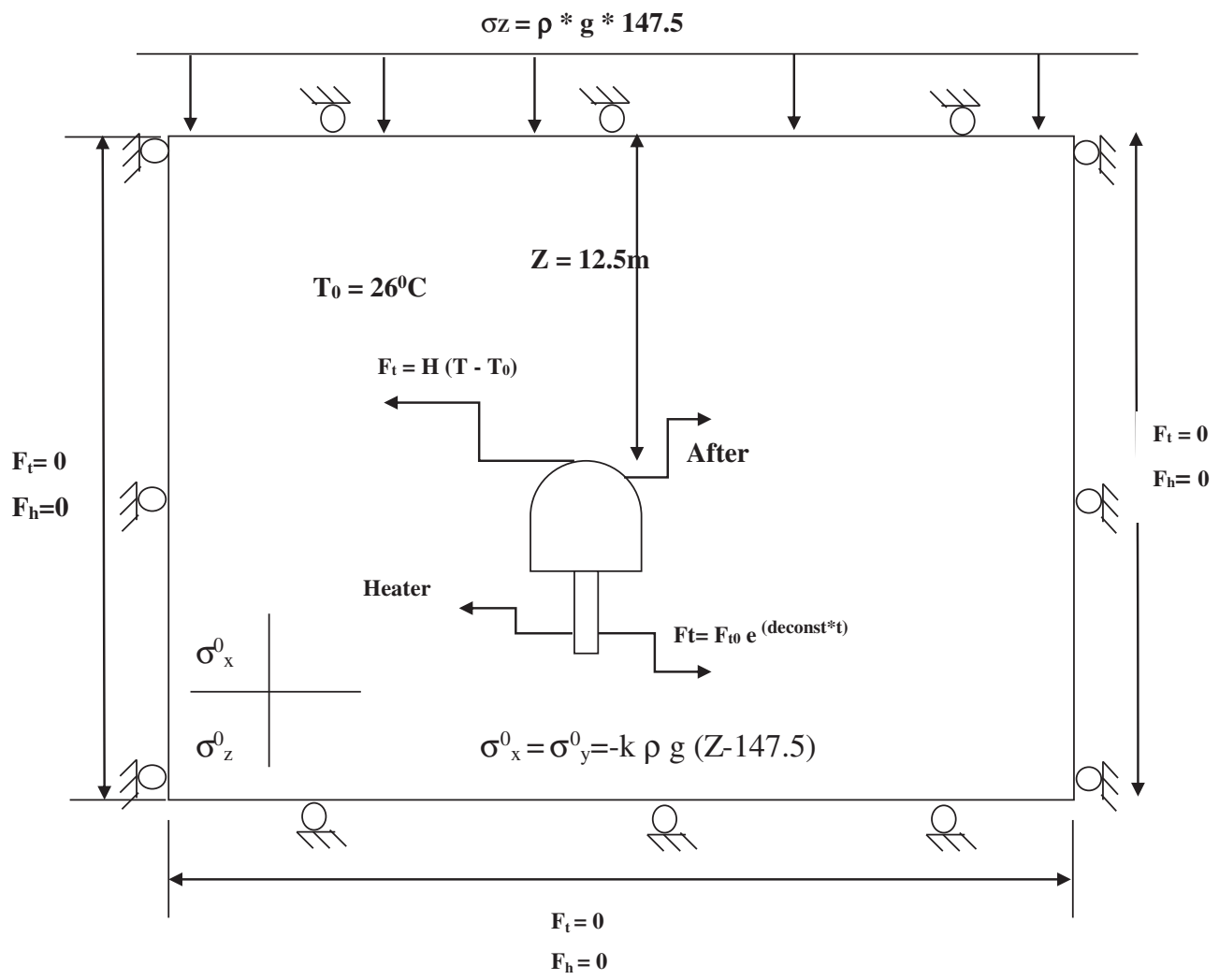

Figure 6. Boundary and initial conditions of the model. Ft: thermal flux, Fh: hydraulic flux, T: temperature, P: hydraulic pressure, t: time, k: coefficient of earth pressure, $\mathrm{Z}$ : z-coordinate, $\sigma_{\mathrm{x}}^{0}, \sigma_{\mathrm{z}}^{0}$ : normal stresses and $\mathrm{H}, \mathrm{F}\left(\mathrm{t}_{0}\right)$, deconst: constant.

Table 3. Physico-mechanical properties of granitic rock samples.

\begin{tabular}{lcccc}
\hline Properties & Unit & $\begin{array}{c}\text { Rock } \\
\text { (granite) }\end{array}$ & $\begin{array}{c}\text { Buffer } \\
\text { (compacted clay) }\end{array}$ & Canister \\
\hline Shear modulus & $\mathrm{GPa}$ & 20.10 & 0.243 & 75.15 \\
Bulk modulus & $\mathrm{GPa}$ & 33.05 & 0.321 & 161.3 \\
Density & $\mathrm{kg} / \mathrm{m}^{3}$ & 2600 & 2050 & 5900 \\
UCS & $\mathrm{MPa}$ & 100.00 & 7.66 & - \\
Tensile strength & $\mathrm{MPa}$ & 10.5 & - & - \\
Friction angle & & 58 & 48 & - \\
Cohesion & $\mathrm{MPa}$ & 60 & 1.5 & - \\
In situ stress ratio, K & - & 1.5 & 0 & - \\
GSI & - & 70 & - & - \\
\hline
\end{tabular}

Table 4. Thermal properties of granite and buffer.

\begin{tabular}{lcccc}
\hline Material type & Unit & $\begin{array}{c}\text { Rock } \\
\text { (granite) }\end{array}$ & $\begin{array}{c}\text { Buffer } \\
\text { (compacted clay) }\end{array}$ & Canister \\
\hline Thermal conductivity & $\mathrm{W} / \mathrm{m}^{\circ} \mathrm{K}$ & 2.30 & 1.65 & 48 \\
Specific heat & $\mathrm{J} / \mathrm{kg}^{\circ} \mathrm{K}$ & 1510 & 875 & 415 \\
Thermal expansion & $1 /{ }^{\circ} \mathrm{K}$ & $2.10 \mathrm{e}-5$ & $3.5 \mathrm{e}-4$ & $1.5 \mathrm{e}-5$ \\
\hline
\end{tabular}

Table 5. Hydraulic properties of granite and buffer.

\begin{tabular}{llll}
\hline Material type & Unit & Rock & Buffer \\
\hline Porosity & - & 0.05 & 0.3 \\
Permeability & $\mathrm{m}^{2}$ & $4.26 \mathrm{e}-16$ & $2.0 \mathrm{e}-19$ \\
Fluid tensile strength & $\mathrm{Pa}$ & $-1.5 \mathrm{e} 9$ & \\
Fluid density & $\mathrm{kg} / \mathrm{m}^{3}$ & $1.5 \mathrm{e} 2$ & \\
\hline
\end{tabular}




\section{Validation}

The suitability and capability of FLAC ${ }^{3 \mathrm{D}}$ for its application to thermo-hydro-mechanical analysis has been verified and a comparison has been made with a published literature (Chan et al. 1995; Verma et al. 2010, 2013). Geometry and boundary conditions have been shown in figure 7 . For validation phase, the same boundary condition (as published in the literature) has been considered.

The pattern of displacement vector is somewhat different because fluid modelling is not included. But overall, the validation case of $\mathrm{FLAC}^{3 \mathrm{D}}$ matches well with literature.

The boundary conditions used in the FLAC ${ }^{3 \mathrm{D}}$ simulation is same as used in the benchmark test 2 (BMT2), DECOVALEX Phase I. A heat flux of $50 \mathrm{~W} / \mathrm{m}^{2}$ has been applied at the left end of the model in the region is shown in figure 7 . Joints in the model have been simulated using interface element with given stiffness from the test case. From figures 8 and 9 , it can be concluded that the temperature distribution between the two models are in good agreement. A small difference is observed at the end of the rectangular model. This may be because fluid simulation has not been done in this model.
Fluid will flow from right wall to left wall due to pressure difference as shown in figure 8. Due to fluid flow, heat transfer takes place by advection from left to right and the convex contour of temperature gradient (in case of thermo-mechanical analysis only) may become straight. This assessment is purely based on qualitative analysis/reasoning and not on any numerical or quantitative analysis. It is also concluded that a combination of different numerical methods like finite element, finite difference, finite volume and their combination can better predict the THM behaviour.

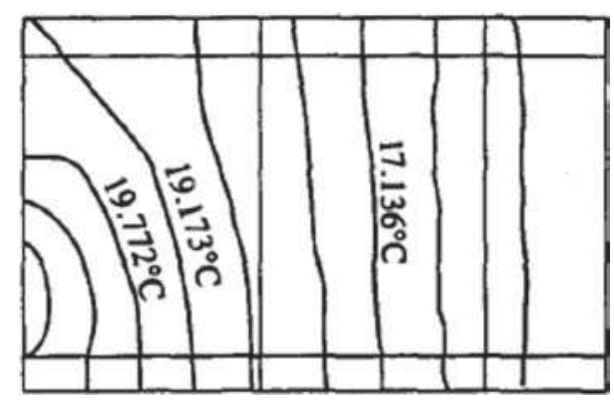

Figure 8. Temperature distribution from bench mark test 2 (BMT2), DECOVALEX Phase I.

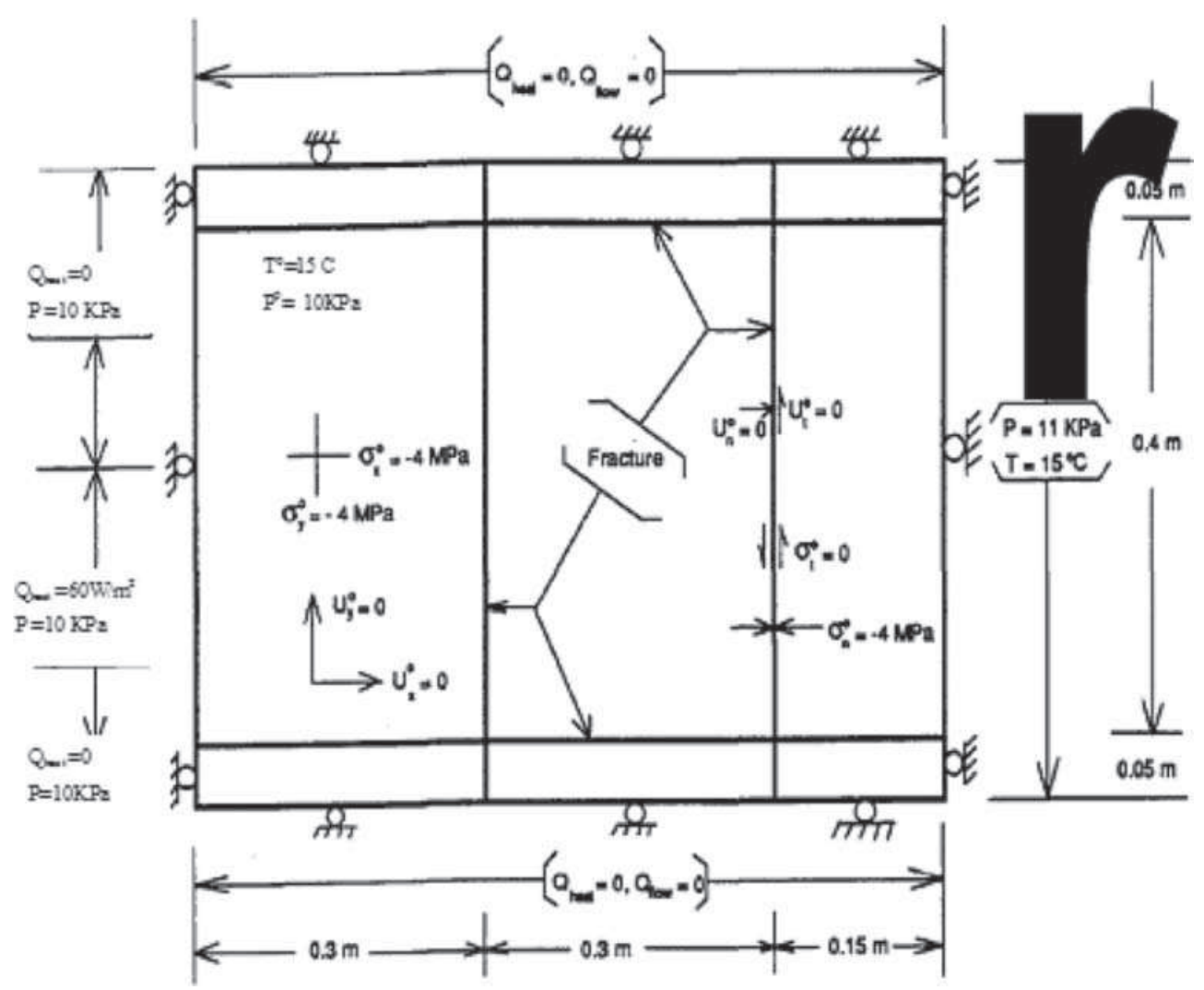

Figure 7. Geometry and boundary conditions for the multiple fracture model, bench mark test 2 (BMT2), DECOVALEX Phase I. 


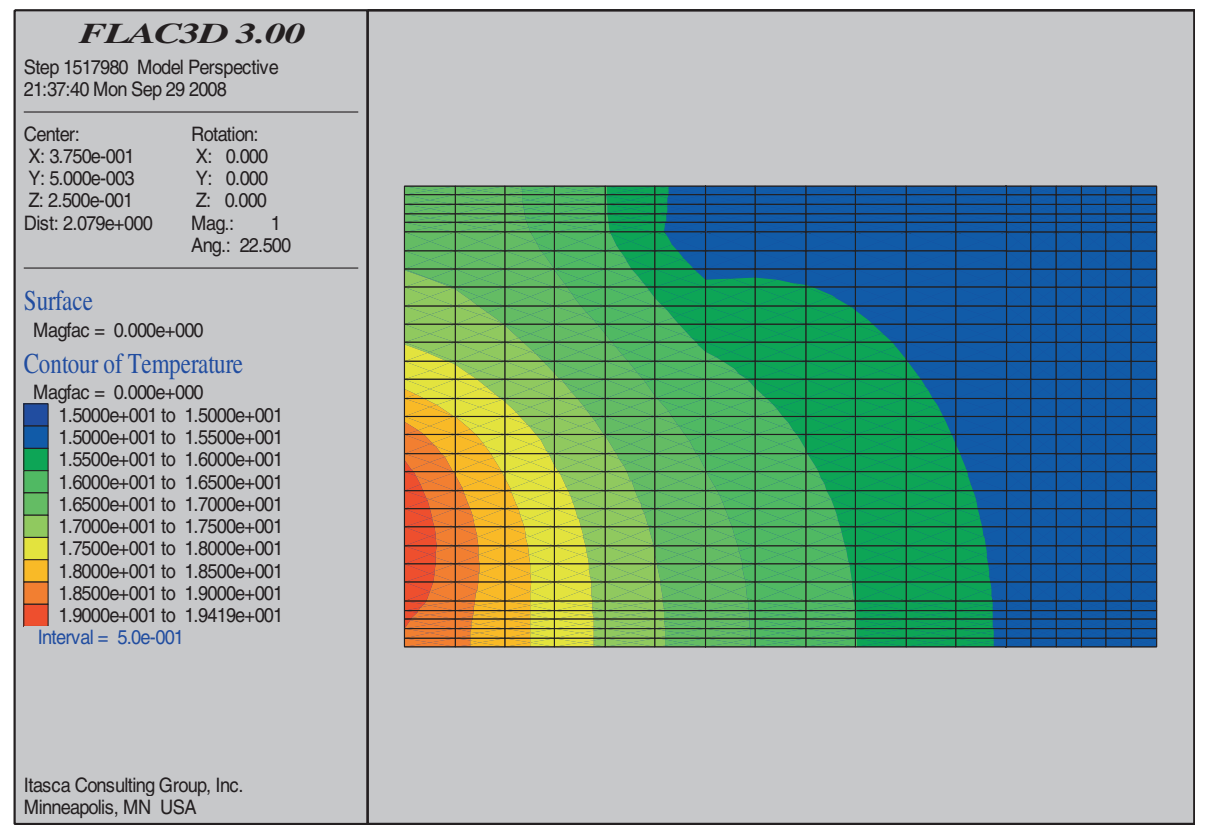

Figure 9. Temperature distributions from FLAC ${ }^{3 \mathrm{D}}$.

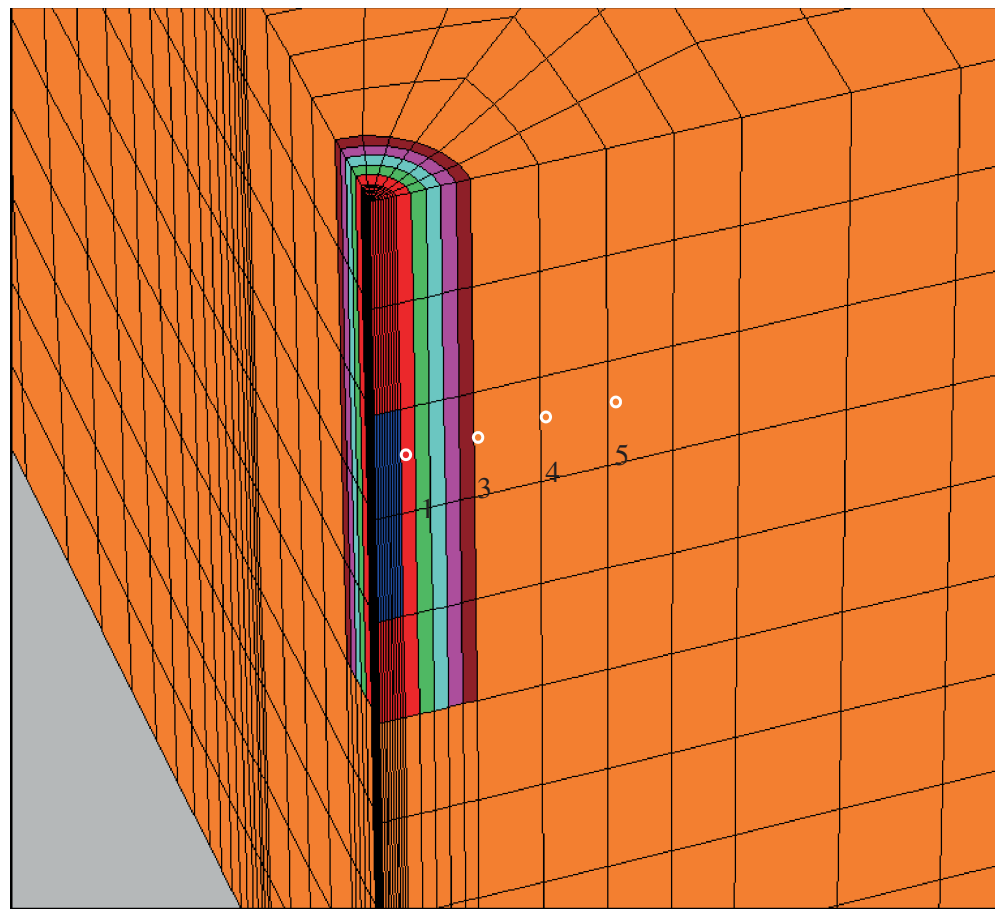

Figure 10. Location of monitoring points.

\section{Results and discussions}

Point 1 is located at the interface of the canister and the barrier; points 3 is located at the interface of barrier and granite, points 4 and 5 are located in the granite (figure 10). Parameters like temperature, displacement, stresses, etc., have been monitored with respect to time. Temperature at the canister and clay barrier has reached a maximum of $59^{\circ} \mathrm{C}$ after 60 days and then decreases exponentially $36^{\circ} \mathrm{C}$ after 6 years. Figure 11 indicates that temperature at any point will never increase the designed maximum temperature of $100^{\circ} \mathrm{C}$ as the temperature of other monitoring points will always be less than the maximum of $59.8^{\circ} \mathrm{C}$. For example, temperature at point 3 at the barrier and granite 


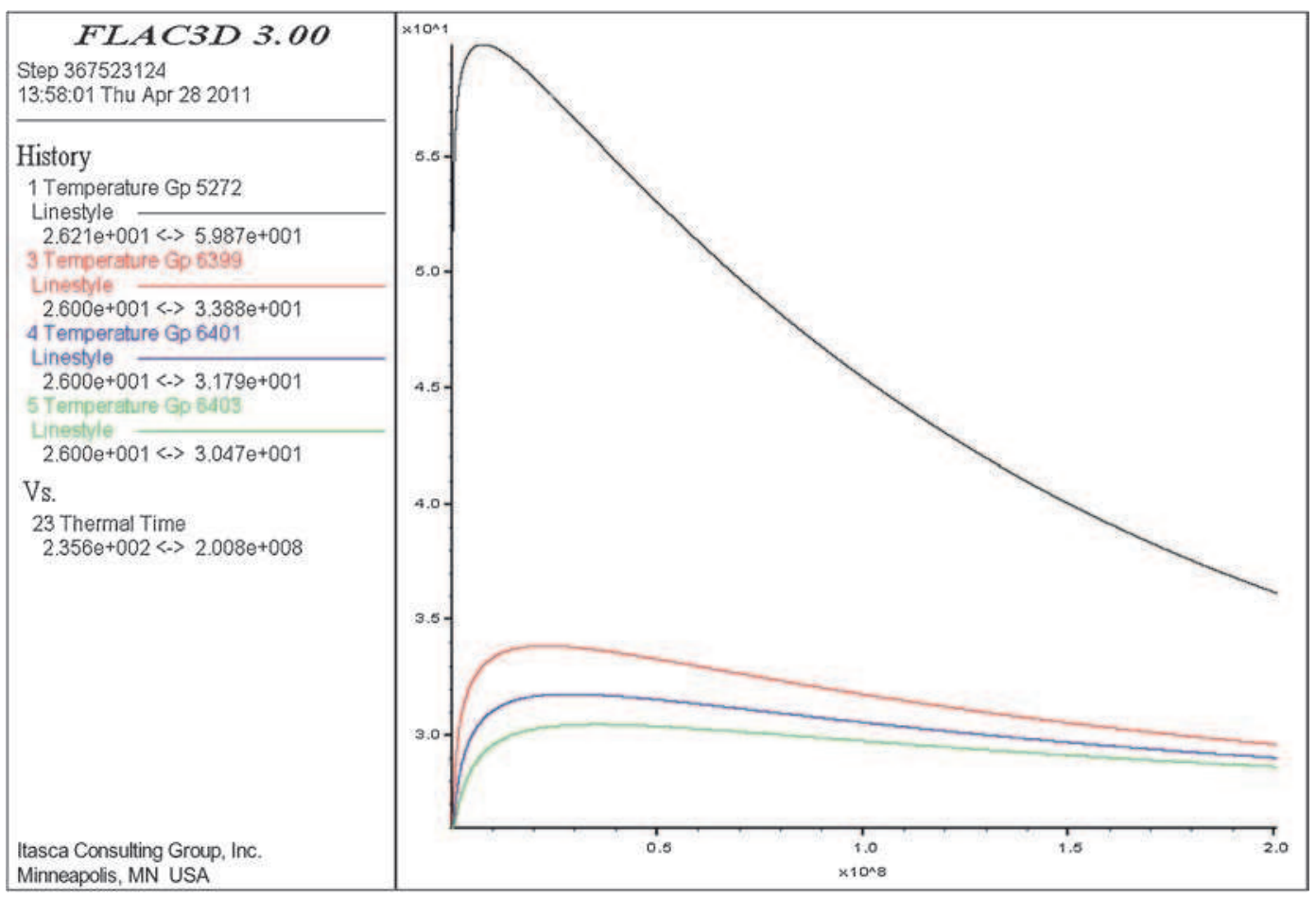

Figure 11. Temperature variations with time at points 1, 3, 4 and 5 of a single pit mode repository.

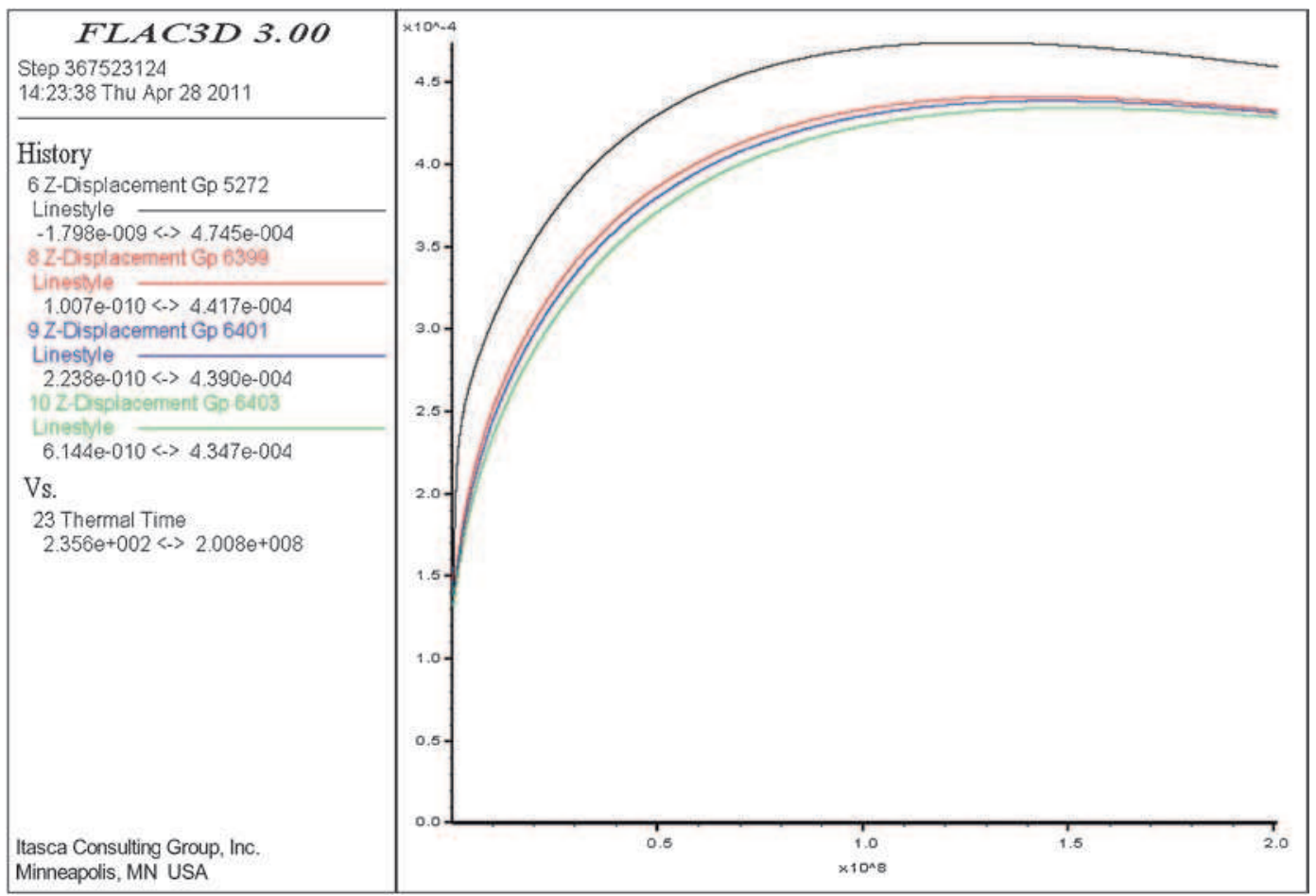

Figure 12. Vertical displacement variations with time at points 1, 3, 4 and 5 of a single pit mode repository.

interface has reached maximum of $34^{\circ} \mathrm{C}$ and then decreases after 120 days. Similar are the cases with points 4 and 5 . Evolution of temperature contour is shown in figure 14, time at which temperature has reached its maximum value respectively. Temperatures all along the clay barrier were $33^{\circ}-35^{\circ} \mathrm{C}$ after 6 years, while it is $35^{\circ}-36^{\circ} \mathrm{C}$ at the canister and clay interface (figures 11,14 ). The area swept by heat front after 6 years is more than the area of heat front at the peak temperature but the magnitude of the temperature is less (figure 14). This means that temperature at intersection of the floor and side wall will increase by maximum of $2^{\circ}-4^{\circ} \mathrm{C}$. 
The evolutions of the vertical displacement of the ground (uplift) and the vertical displacements of the repository structure and of the limits of the clay barrier is shown in figure 12. As shown in figure 12, vertical displacement is $0.46 \mathrm{~mm}$ for point 1, which is at the interface of canister and clay barrier. The vertical displacement is increasing exponentially and reached peak of $0.46 \mathrm{~mm}$ after 2 years. Other monitoring points in granite follow the same trend. For example, point 3 reached peak vertical displacement of $0.44 \mathrm{~mm}$.

After 6 years, crown of the tunnel has converged $0.5 \mathrm{~mm}$ downwards while top of the clay barrier has undergone heaving effect and has a vertical upward displacement of $0.5-1 \mathrm{~mm}$ (figure 12). The heaving effect was due to the heat released by the canister which has expanded the clay at the top of the clay barrier. Floor of the tunnel has undergone heaving from 0.5 to $4 \mathrm{~mm}$

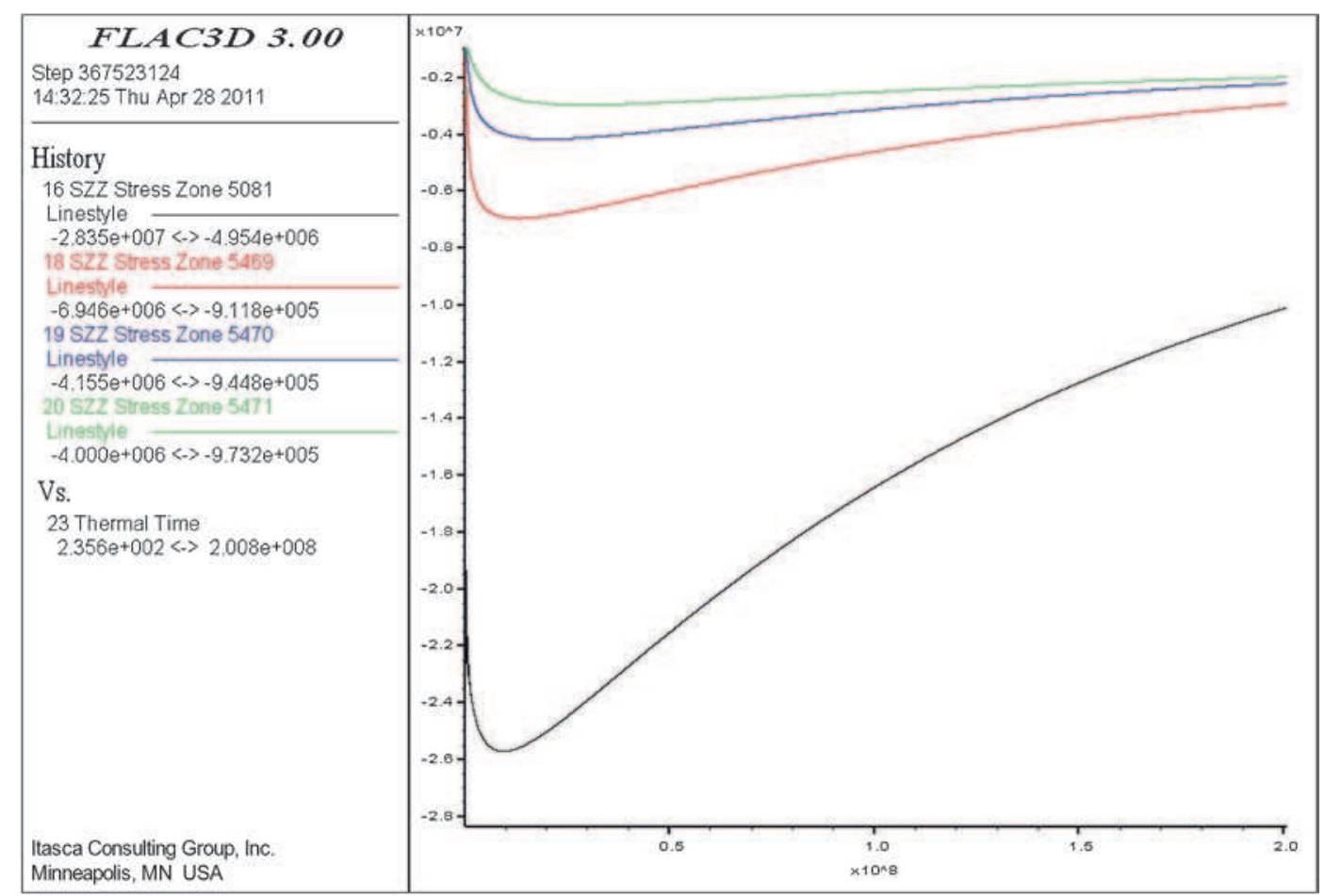

Figure 13. Vertical stresses variation with time at points 1, 3, 4 and 5 of a single pit mode repository.

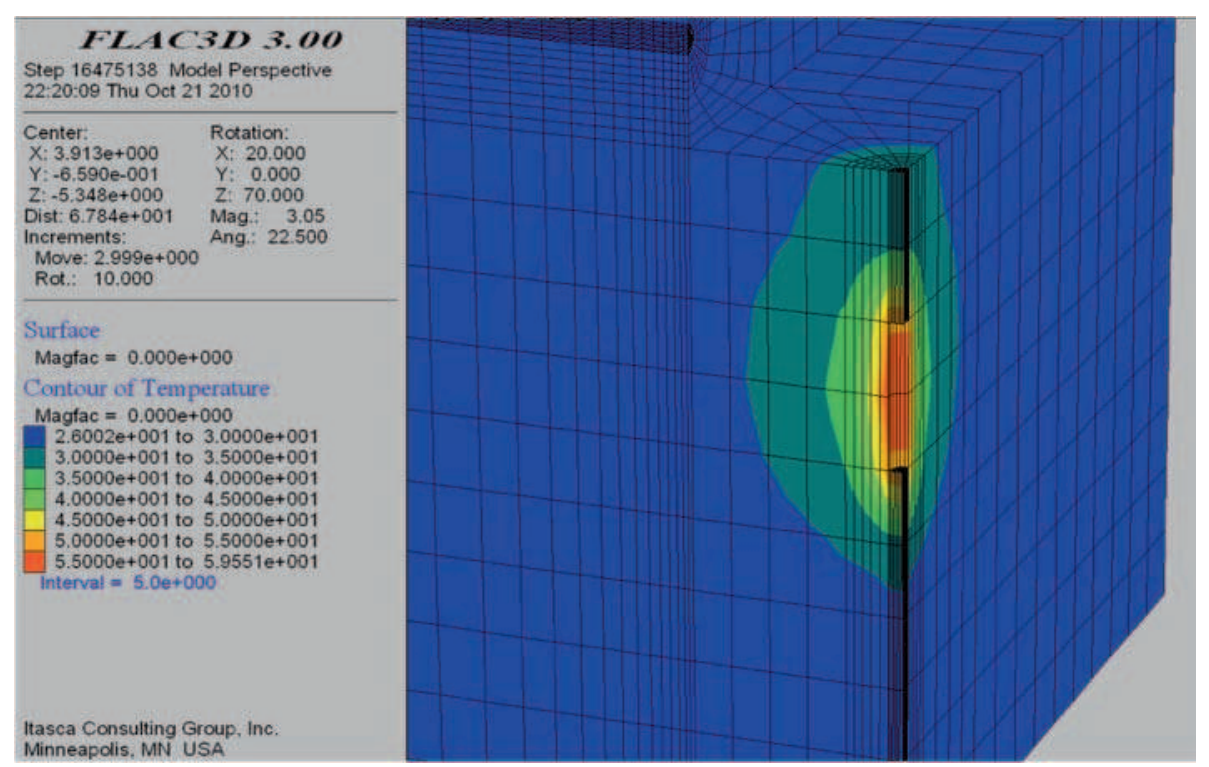

Figure 14. Temperature distributions at the canister-barrier interface of the single pit mode repository at peak temperature of $59.8^{\circ} \mathrm{C}$. 
in the upward direction. At the peak temperature of $59.8^{\circ} \mathrm{C}$, top of the barrier had undergone heaving effect of $5 \mathrm{~mm}$ while bottom of the barrier had moved to $3.04 \mathrm{~mm}$ in negative downward direction. This is due to the expansion of clay with heating (figure 15).
Vertical stresses were monitored at the zones associated with grid points 1, 3, 4 and 5. During initial few days, the vertical stress increases suddenly to $22 \mathrm{MPa}$ at the canister and clay barrier interface and reached a maximum compressive stress of $26 \mathrm{MPa}$ after 60 days. The vertical compressive

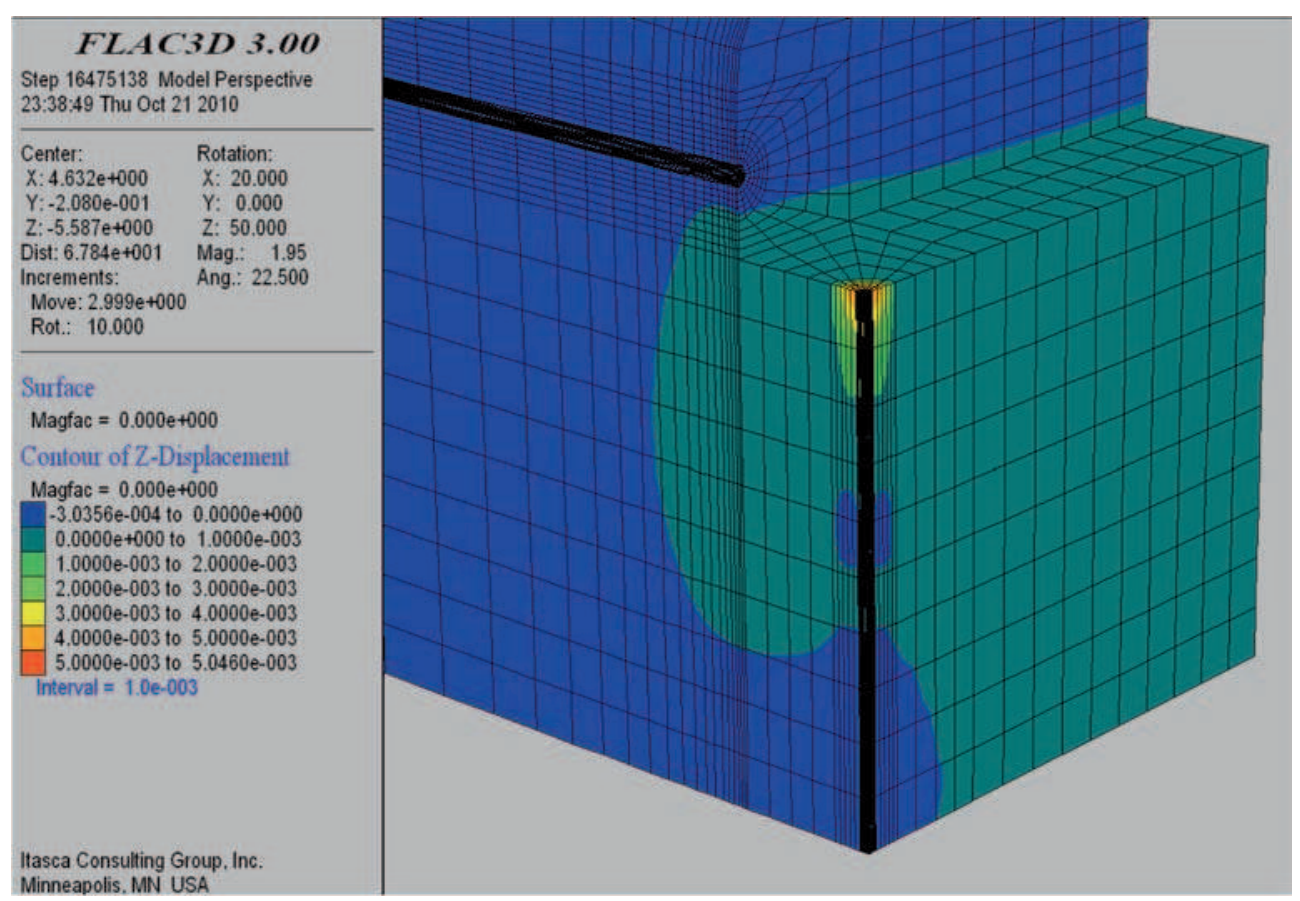

Figure 15. Convergence of the roof and heaving of the floor of the single pit mode repository at the peak temperature of $59.8^{\circ} \mathrm{C}$.

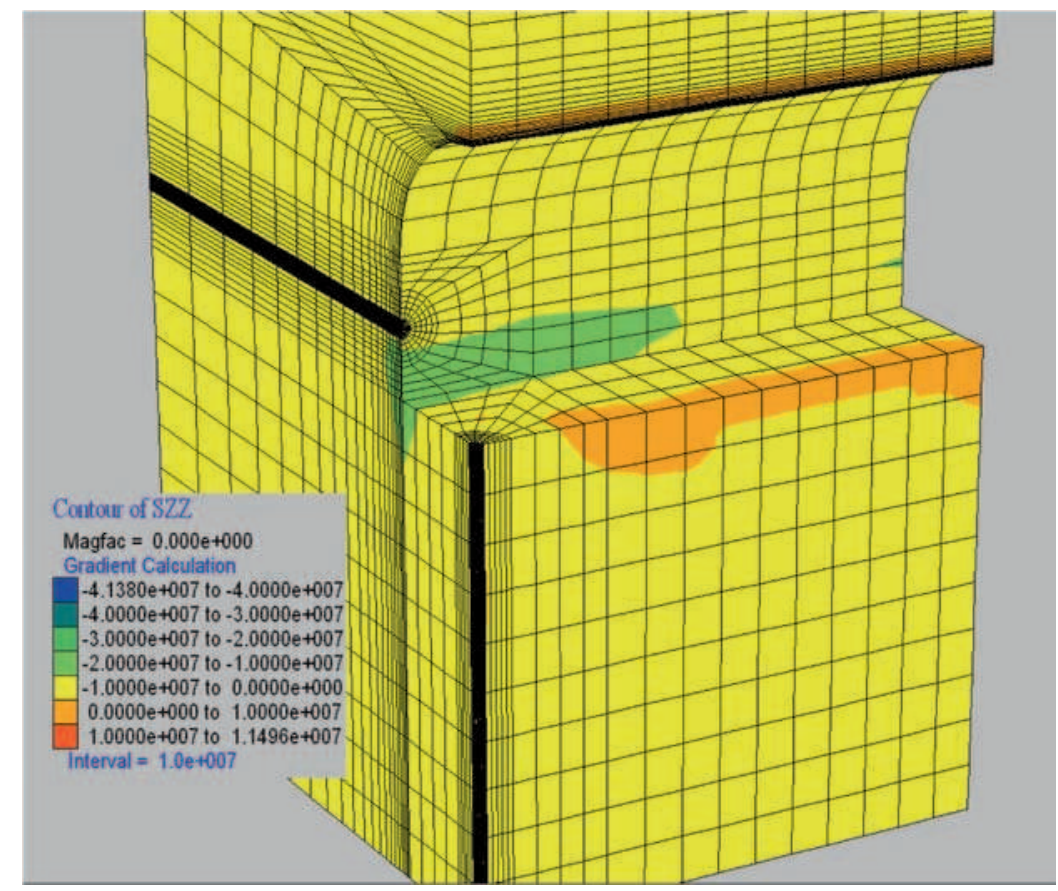

Figure 16. Maximum principal stress distribution of the single pit mode repository at the peak temperature of $59.8^{\circ} \mathrm{C}$. 
stress decreases after 60 days and reaches to $10 \mathrm{MPa}$ after 6 years (figure 13). Similarly, point 3 has reached a maximum of $6 \mathrm{MPa}$ and then decreases to $3 \mathrm{MPa}$ after 6 years of heat decay from spent fuel. Since compressive stress in the buffer zone is in the range of $2-26 \mathrm{MPa}$ for continuous 2 years, the composition of engineered barrier should be modified to gain higher strength within 2 years of time span or power of the spent nuclear fuel should be reduced to generate compressive stress in the buffer within the limit of its compressive strength (figures 14 and 15).

Some part of the crown, floor of the tunnel and canister-clay interface experience maximum tensile stresses of $1.17 \mathrm{MPa}$. Since rocks are weak in tension, there is greater chance of failure at these
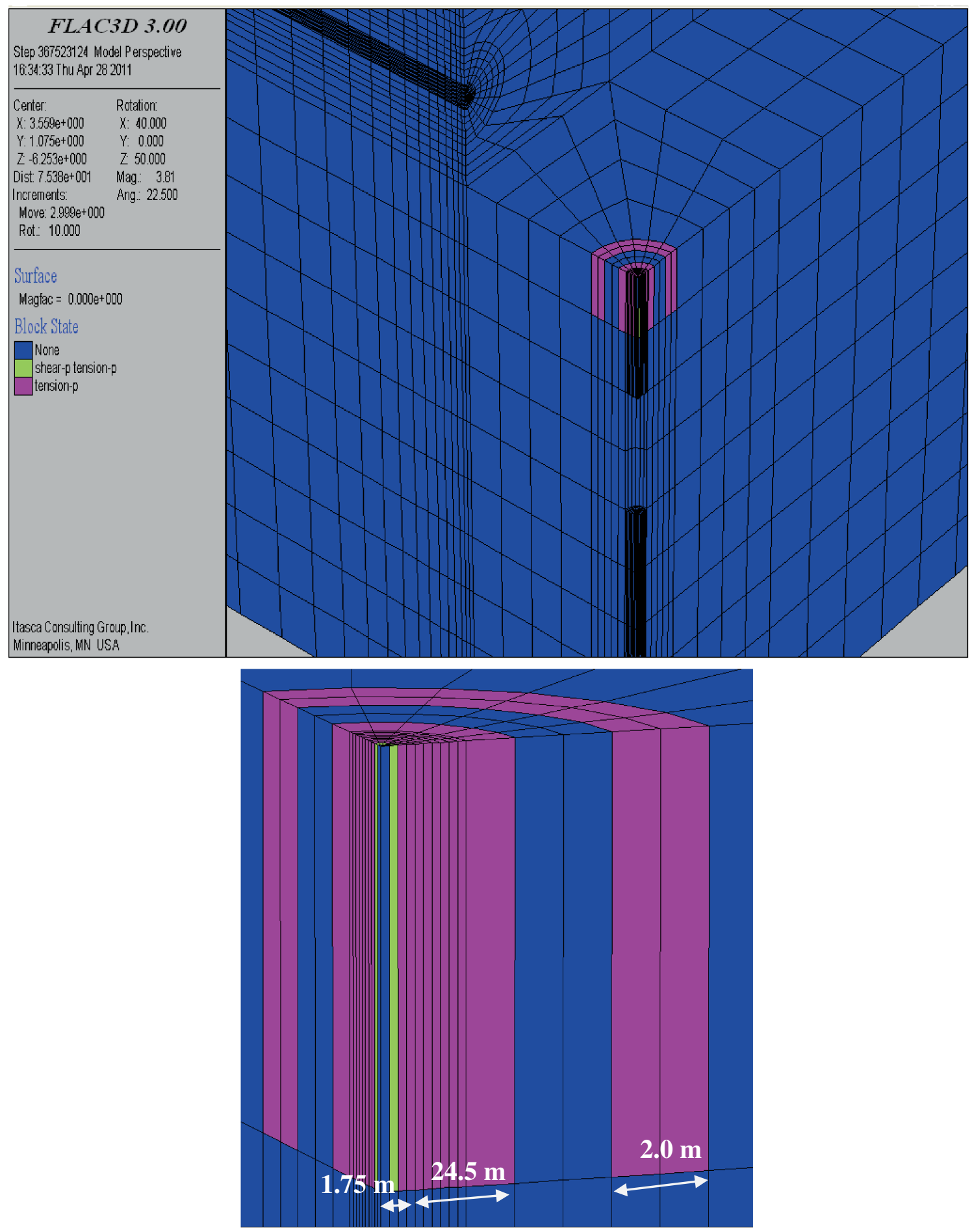

Figure 17. State variables of the vertical pit after 6 years of heat decay by spent fuel. 


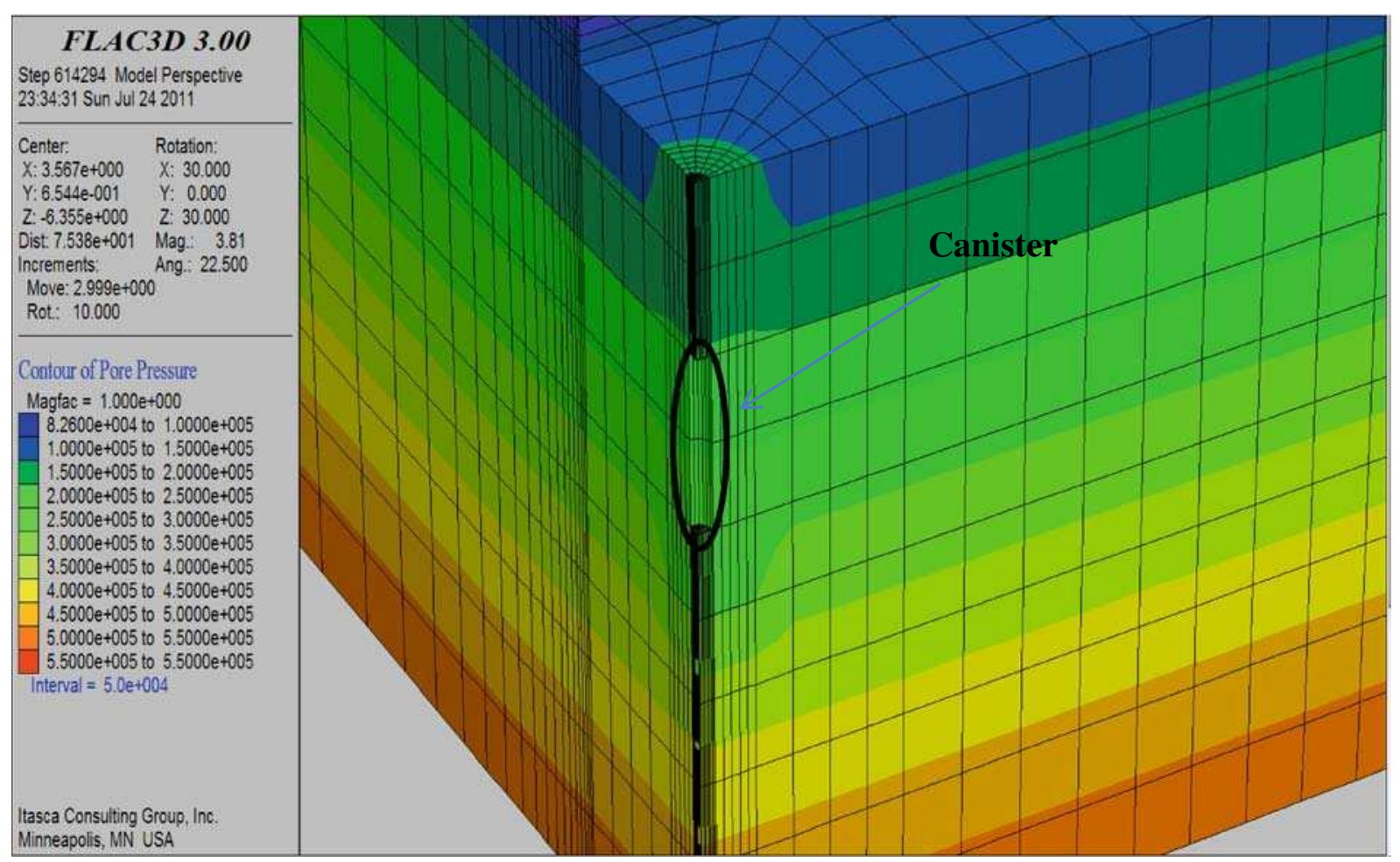

Figure 18. Pore pressure distribution of the single pit mode repository after 6 years.

surfaces as compared to compressive stresses at the rest of the tunnel. At the peak temperature, tensile stresses reached to maximum of $11 \mathrm{MPa}$ which is near the tensile strength of the granitic rock used in the URL. Hence, even at the peak temperature of $59.8^{\circ} \mathrm{C}$, there is a chance of local tensile failure (figure 13). Maximum principal stress of $39 \mathrm{MPa}$ is generated in the single pit repository at the peak temperature of $59.8^{\circ} \mathrm{C}$ (figure 16).

Figure 17 indicates whether stresses within a zone are currently on the yield surface (i.e., the zone is at active failure now, $-n$ ), or the zone has failed earlier in the model run, but now the stresses fall below the yield surface (the zone has failed in the past, $-\mathrm{p}$ ). Initial plastic flow can occur at the beginning of a simulation, but subsequent stress redistribution unloads the yielding elements so that their stresses no longer satisfy the yield criterion, indicated by shear-p or tension-p (on the plasticity state plot). Clay above the canister undergoes shear and tension in the past after 6 years of heat decay by spent fuel. The maximum width of the plastic domain (shear in past) was approximately $1.75 \mathrm{~m}$ at the top of the canister but in the clay barrier. Six years after placement of nuclear waste canister, width of the plasticized area (area under tension) reached $2.45 \mathrm{~m}$ and $2.0 \mathrm{~m}$ measured from the center of the canister at the top of the canister in the clay. The issue of crack development and subsequent fall in mechanical strength is very

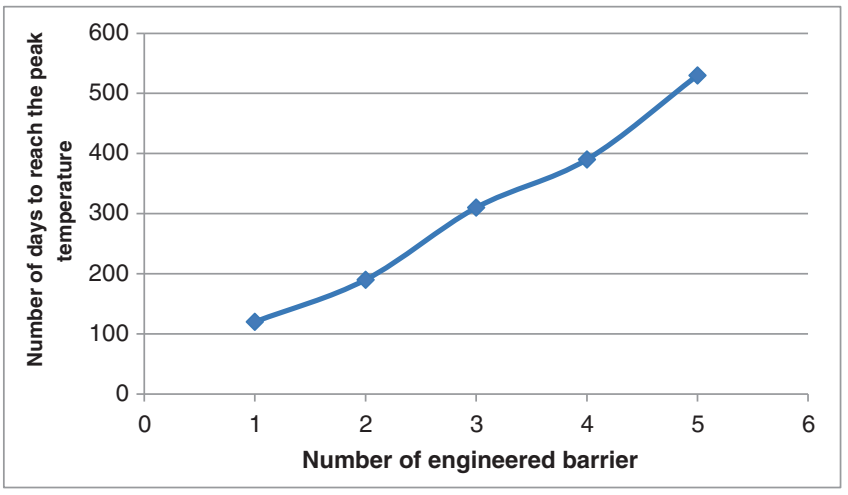

Figure 19. Variation of thickness of engineered barrier with time to reach the maximum temperature.

important for long term stability of any geological repository. Explicit modelling of crack development and its effect on the mechanical strength would help the future research for indigenous development of spent fuel repository.

Figure 18 shows the variation of pore pressure after 6 years of heat decay. Due to heating, the pore pressure front at the top of canister has moved in upward direction, while the front has moved downwards for the bottom of canister. $0.2-0.3 \mathrm{MPa}$ of pore pressure was developed in the vicinity of the canister. Maximum pore pressure of $0.55 \mathrm{MPa}$ was developed at the base of the model. 


\section{Effect of thickness of engineered barrier}

Size of the engineered barrier has varied from a diameter of 0.55 to $1.35 \mathrm{~mm}$ (table 2 and figure 5). Maximum temperature was recorded at monitoring point 3 for the five cases and time taken to reach the maximum temperature was recorded as shown in figure 19. As the thickness of the engineered barrier increases, time taken for temperature to reach the maximum value also increases (figure 19). This is due to increasing thickness of the engineered barrier which decreases the heat transfer capacity of the barrier (because of the increase of equivalent heat capacity).

\section{Conclusion}

The coupled THM behaviour of the porous media has been widely analyzed in this study using finite difference tool. The analysis was directed to the interaction among spent fuel canister, clay barrier and the host rock in the near field. The excavation phases were carried out in order to obtain a suitable stress state, deformations and temperature values in the near field. Once this is established, the numerical simulation covers the emplacement of canister containing spent fuel, clay barrier buffer emplacement, heating phase and cooling phase. The high heat capacity of clay barrier helps to retain heat up to its full capacity.

Clay near to canister experienced maximum temperature of $60^{\circ} \mathrm{C}$ in 60 days. The simulation showed that with the granite, clay barrier and canister properties, the temperature in the repository will never increase above $60^{\circ} \mathrm{C}$. At the peak temperature of $59.8^{\circ} \mathrm{C}$, top of the clay barrier had undergone heaving effect with maximum vertical upward displacement of $5 \mathrm{~mm}$ after 6 years of the disposal of the vitrified waste. Clearly, most of the uplift has been attributed to the clay barrier. Hence, the deformation in any part of repository will never increase to $25 \mathrm{~mm}$. As the thickness of engineered barrier increases number of days taken to reach the maximum temperature for a particular point in the rock mass also increases. Considering this and the requirement of enhanced compressive strength of engineered barrier, as discussed in Results and Discussion section, we conclude that the design should be modified for design of long term stable nuclear waste repository.

It is difficult to model complicated geometry and physical processes using finite difference method, assembly of different material components and combination of various types of elements (1-D, 2$\mathrm{D}$ and $3-\mathrm{D})$. Hence, it is suggested to use a combination of different numerical methods like finite element, finite volume and their combinations which are more accurate.

\section{References}

Alonso E E, Alcoverro J, Coste F, Malinsky L, MerrienSoukatchoff V, Kadiri I, Nowak T, Shao H, Nguyen T S, Selbadurai A P S, Armand G, Sobolik S R, Itamura M, Stone C M, Webb S W, Regeb A, Tijani M, Maouche Z, Kobayashi A, Kurikami H, Ito A, Sugita Y, Chijimatsu M, Börgesson L, Hernelind J, Rutqvist J, Tsang C F and Jussila P 2005 The FEBEX benchmark test: Case definition and comparison of modelling approaches; Int. J. Rock Mech. Min. Sci. 42 611-638.

Berchenko I 1998 Thermal loading of saturated rock mass: Field experiment and modeling using thermoporoelastic singular solutions; Dissertation, Minneapolis: University of Minnesota.

Booker J R and Savvidou C 1985 Consolidation around a heat source; Int. J. Rock Mech. Min. Sci. 9 173-184.

Chan T, Schair K, Jing L, Ahola M, Noorishad J and Vuillod E 1995 International comparison of coupled thermo-hydro-mechanical models of a multiple fracture benchmark problem: DECOVALEX phase I, Bench Mark Test 2, Int. J. Rock Mech. Min. Sci. \& Geomech. Abstracts 32 435-453.

Chijimatsu M, Fujita T, Sugita Y, Amemiya K and Kobayashi A 2001 Field experiment results and THM behavior in the Kamaishi mine experiment; Int. J. Rock Mech. Min. Sci. 38 67-78.

Dutt A, Saini M S, Singh T N, Verma A K and Bajpai R K 2012 Analysis of thermo-hydrologic-mechanical impact of repository for high-level radioactive waste in clay host formation: An Indian reference disposal system; Environ. Earth Sci. 66(8) 2327-2341.

EURATOM 2000 Full-scale engineered barriers experiment for a deep geological repository for high-level radioactive waste in crystalline host rock (FEBEX project). Report EUR 19147, Directorate-General for Research, European Commission, rue de la Loi/Wetstraat 200, B-1049 Brussels.

Graham J, Chandler N A, Dixon D A, Roach P J, To T and Wan A W L 1997 The buffer/container experiment: Results, synthesis, issues, Atomic Energy of Canada Limited Report, AECL-11746, COG-97-46-1. AECL, Ontario, Canada.

Guo Ruiping and Dixon David 2006 Thermohydromechanical simulations of the natural cooling stage of the Tunnel Sealing Experiment; Eng. Geol. 85 313-331.

Guvanasen V 1985 Development of a three-dimensional finite element code and its application to geoscience research, 17th Information Meeting of the Nuclear Fuel Waste Management Program, Atomic Energy of Canada Limited, Technical Report TR-299, AECL, Ontario, Canada.

Hoek E, Carranza-Torres C and Corkum B 2002 HoekBrown Failure Criterion - 2002 edn, Proc. NARMS-TAC Conference Toronto 1 267-273.

ISRM 1981a Rock characterization testing and monitoring; In: ISRM suggested methods, Int. Soc. for Rock Mech. 211p.

ISRM 1981b Suggested method for determining the uniaxial compressive strength of rock materials, rock characterization, testing and monitoring; Int. J. Rock Mech. Min. Sci., Geomech. Abstr, 113p.

Jing L, Tsang C-F and Stephansson O 1995 DECOVALEX - An international co-operative research project on mathematical models of coupled THM processes for safety analysis of radioactive waste repositories (special issues 
on THM coupling in rock mechanics); Int. J. Rock Mech. Min. Sci. 32 387-398.

KAERI 2005 Long-Term Heat Load Calculation Methodology for Spent Nuclear Fuel; Korea Atomic Energy Research Institute, KAERI/TR-3031/2005.

Kjartanson B H and Gray M N 1987 Buffer/Container Experiments in the Underground Research Laboratory; Proceedings of the 40th Canadian Geotechnical Society Conference, Regina, SK.

Ledesma A and Chen G J 2003 T-H-M modelling of the Prototype Repository Experiement: Comparison with current measurements; In: Proceedings of the International Symposium on Large Scale Field Tests in Granite (eds) Alonso E E and Ledesma A, Sitges, Barcelona, Spain, 12-14th Nov. 2003, Advances in Understanding Engineered Clay Barriers, Balkema, pp. 339-346.

Mathur R K, Narayan P K, Joshi M R and Rakesh R $\mathrm{R} 1998$ In situ multi-heater thermomechanical experiments in Mysore Mines, Kolar gold fields, Bhabha Atomic Research Centre, Mumbai, India, BARC/1998/I/015.

Radhakrishna H S, Crawford A M, Kjartanson B H and Lau K C 1992 Numerical modelling of heat moisture transfer through bentonite-sand buffer; Canadian Geotech. J. 29 1044-1059.

Raj K, Prasad K K and Bansal N K 2006 Radioactive waste management practices in India; Nuclear Engineering and Design 236(7-8) 914-930.

Rutqvist J, Barr D, Datta R, Gens A, Millard A, Olivella S, Tsang C F and Tsang Y 2005 Coupled thermalhydrological-mechanical analyses of the Yucca Mountain
Drift Scale Test - Comparison of field measurements to predictions of four different numerical models; Int. J. Rock Mech. Min. Sci. 42 680-697.

Sillen X 2008 Modelling the thermal impact of a repository for high-level radioactive waste in a clay host formation, COMSOL Conference - Hannover 2008.

Stephansson O, Hudson J A, Tsang C-F, Jing L and Anderson J 1999 DECOVALEX II Project: Coupled THM issues related to repository design and performance Task 4. SKI Report 99:7.

Thomas H R, He Y, Sansom M R and Li C R W 1996 On the development of a model of the thermo-mechanical-hydraulic behaviours of unsaturated soils; Eng. Geol. 41 197218.

Thomas H R, He Y and Onofrei C 1998 An examination of the validation of a model of the hydro/thermo/ mechanical behaviour of engineered clay barriers; Int. J. Num. Anal. Meth. Geomech. 22 49-71.

Thomas H R, Cleall P J and Melhuish T A 2003 Simulation of the Tunnel Sealing Experiment using THM modelling; No. 06819-Rep-01200-10112-R00, Ontario Power Generation Inc., Nuclear Waste Management Division Report, Toronto.

Verma A K, Bajpai R K, Singh T N, Narayan P K and Avi Dutt 2010 3D instability analysis of an underground geological repository - An Indian case study; Arabian J. Geosci., doi: 10.1007/s12517-010-0131-4.

Verma A K, Saini M S, Singh T N, Avi Dutt and Bajpai R K 2013 Effect of excavation stages on stress and pore pressure changes for an underground nuclear repository; Arabian J. Geosci. 6(3) 635-645. 